\title{
Effects of Glass Ceiling on Women Career Development in Private Sector Organizations - Case of Sri Lanka
}

\author{
Bombuwela P. M., De Alwis A. Chamaru
}

\begin{abstract}
The study was entirely designed by centering the focal problem of the effect of Glass Ceiling on Women Career Development. The overall study was structure based on the conceptual framework built up using the information of literature survey. The study was conducted with the aim of obtaining the following objective. That is "To find out the Effect of Glass Ceiling on Women Career Development with regard to female executive level employees who are working in private sector organizations." At the same time, hypotheses are developed to find out whether there is a significant effect of Individual Factors, Family Factors, Organizational Factors and Cultural Factors on Women Career development. Merely this study has been completed with an empirical survey which was thoroughly conducted using a self-administered questionnaire and the sample consisted of 150 women executives. For presenting and analyzing the data both descriptive and inferential statistics were used. The findings reveal that the Glass Ceiling and Women Career Development have a moderate negative relationship, and also show that Individual Factors, Organizational Factors and Cultural Factors have a significant effect on Women Career Development whereas Family Factor has effects on the Glass Ceiling. Following the study results, a conclusion was eventually made that there are significant effects of the Glass Ceiling on Women Career Development of Executive level female employees working in private sector organizations in Sri Lanka. By taking all these facts into consideration, better recommendations have been made in this study. Finally, the most valuable suggestions for further studies and limitations of the study have been outlined.
\end{abstract}

Key words: Glass Ceiling, Women Career Development, Individual Factors, Family Factors, Organizational Factors, Cultural Factors, Career Focused, Family Support, Attitudes towards Organization

\section{INTRODUCTION}

In recent years, women as well as gender issues have turn into a major area of concern. Seminars, workshops are being held over the world to discuss women issues and women progression in all area of life. That is because of the most significant features of the global labor market in the last half of the twentieth century, which is increasing the participation of women. (Black, Gregerson, Mendenhall and Stroh, 1999; Caligiuri and Tung, 1999).Some studies illustrate that during the last two decades there has been an increase in the proportion of women at entry and middle-level management positions, resulting largely from the activities of the women's movement, policies of the political system, and corporate equal opportunity initiatives. However according to Meyerson \& Fletcher (2000) women at the highest levels of business are still rare. They comprise only $10 \%$ of senior managers in Fortune 500 companies; less than $4 \%$ of the uppermost ranks 
of CEO, president, executive vice president, and COO; and less than 3\% of top corporate earners. Not only that there is strong evidence of the under-representation of women in leadership positions in many countries all over the world such as Australia (Davidson, 2009; Maginn, 2010; Still, 2006), China (Tan, 2008), France (Barnet-Verzat and Wolff, 2008), South Africa (Booysen and Nkomo, 2010; Mathur-Helm, 2006), United Kingdom (Davidson, 2009; Thomson et al., 2008) and United States (Eagly and Carli, 2007; Fassinger, 2008).

These factors, however, have had limited impact at the level of corporate governance, where women have only a token presence (Adler and Izraeli, 1994; Bilimoria and Piderit, 1994; Directors and Boards, 1992). Although attitude towards the women's role as homemakers is changing to being career people, only some women have made their approach to gradually climb up the management and leadership ladders. For an example from the world situation, the report, from McKinsey and Co., put Korea bottom of a list comparing the percentage of female employees in 744 company executive committees of 10 major Asia-Pacific stock markets. Women take up only 1 percent of boardroom seats in this country, compared with 13 percent in Australia, 8 percent in China and 5 percent in India.

Even though women represent more than half of the population in Sri Lanka, their labour force participation rate is less than men. Men's participation in labour force is twice as women's.

Tab. 1 - Population and Labour Force. Source: Labour Force Survey - Annual Report 2010.

\begin{tabular}{|c|c|c|c|c|c|}
\hline & $\begin{array}{c}\text { Population (10 } \\
\text { years \& over) }\end{array}$ & $\begin{array}{c}\text { Labour } \\
\text { Force }\end{array}$ & $\begin{array}{c}\text { Labour force par- } \\
\text { ticipation rate }\end{array}$ & $\begin{array}{c}\text { Employed } \\
\text { population }\end{array}$ & $\begin{array}{c}\text { Employment } \\
\text { Rate }\end{array}$ \\
\hline Sri Lanka & $16,861,526$ & $8,107,739$ & & $7,706,593$ & $95.1 \%$ \\
\hline Male & $7,919,105$ & $5,317,553$ & 32.9 & $5,131,986$ & $96.5 \%$ \\
\hline Female & $8,942,422$ & $2,790,186$ & 68.8 & $2,574,608$ & $92.5 \%$ \\
\hline
\end{tabular}

In 2010, estimated economically active population is around eight million and about five million $(67.1 \%)$ of them are males. female participation rate is around 31 percent. Majority among the economically inactive population are females $(68.8 \%)$. Report has mentioned some reasons for non participation of women for labour force.

Tab. 2 - Reasons of being economically inactive by gender. Source: Labour Force Survey Annual Report 2010.

\begin{tabular}{|l|c|c|c|}
\hline \multirow{2}{*}{ Reasons } & \multirow{2}{*}{ Total } & \multicolumn{2}{|c|}{ Gender } \\
\cline { 3 - 4 } & & Male & Female \\
\hline All Economically Inactive & 100.0 & 100.0 & 100.0 \\
\hline Engaged in housework & 39.1 & 4.0 & 53.9 \\
\hline Engaged in studies & 36.0 & 58.2 & 26.7 \\
\hline Retired-Old age & 16.1 & 23.1 & 13.1 \\
\hline Physically illness/Disabled & 4.9 & 8.5 & 3.5 \\
\hline Other & 3.9 & 6.3 & 2.9 \\
\hline
\end{tabular}


These findings reveal that housework is the highly affected factor to being women as economically inactive. Table 2 clearly shows that more than 75 percent of inactive population engaged in studies or housework. The main reason for the majority of females $(53.9 \%)$ to be under economically inactive category is that their involvement in housework activities. However that percentage is only $4 \%$ percent for males.

From the portion of labour force participation, men as well as women contribute to employed population in high rates (Table 1). However Ruth (2008), has reported that Sri Lankan women are being providing a large portion of Sri Lanka's factory work. As of 2010, 350,000 women are employed in the country's 850 apparel factories or $85 \%$ of the industry's workforce. That's means women's employment has limited to only some categories.

Tab. 3 - Employed population by Occupation. Source: Labour Force Survey - Annual Report 2010.

\begin{tabular}{|c|c|c|c|c|}
\hline \multirow[b]{2}{*}{ Occupation } & \multirow[b]{2}{*}{ Total } & \multicolumn{2}{|c|}{ Gender } & \multirow{2}{*}{$\begin{array}{c}\% \text { Contribution of females } \\
\text { to the total employment }\end{array}$} \\
\hline & & Male & Female & \\
\hline Total & 100.0 & 100.0 & 100.0 & 33.4 \\
\hline Senior Officials \& Managers & 1.5 & 1.7 & 1.1 & 23.7 \\
\hline Professionals & 5.6 & 3.2 & 10.4 & 61.9 \\
\hline $\begin{array}{l}\text { Technical \& Associate Profes- } \\
\text { sionals }\end{array}$ & 5.1 & 5.2 & 4.9 & 32.0 \\
\hline Clerks & 4.1 & 3.4 & 5.5 & 44.5 \\
\hline $\begin{array}{l}\text { Proprietors \& Managers of } \\
\text { Enterprises }\end{array}$ & 6.8 & 7.6 & 5.3 & 25.9 \\
\hline Sales \& Services Workers & 8.1 & 8.3 & 7.8 & 32.0 \\
\hline $\begin{array}{l}\text { Skilled Agri. \& Fishery Work- } \\
\text { ers }\end{array}$ & 22.3 & 21.1 & 24.5 & 36.7 \\
\hline Craft \& Related Workers & 15.7 & 15.6 & 15.8 & 33.6 \\
\hline $\begin{array}{l}\text { Plant / Machine Operators \& } \\
\text { Assemblers }\end{array}$ & 7.3 & 9.9 & 2.0 & 9.0 \\
\hline Elementary Occupations & 22.6 & 22.5 & 22.7 & 33.6 \\
\hline Unidentified & 1.0 & 1.3 & 0.2 & 7.6 \\
\hline
\end{tabular}

Table 3 shows the occupational summary of women and men and also this compares the proportion of men and women employed in different occupational categories. Women are heavily concentrated in certain occupations and 24.5 percent of them are employed in "Skilled Agricultural and Fishery Workers" occupation compared with 21.1 percent of males. Also, 10.4 percent of females work in "Professional" occupation compared with 3.2 percent of males. This tab also shows the contribution of females to the total employment by each occupational group. This clearly shows that 61.9 percent of professional are women. Report mentioned reasons for that, because the occupation group of "Professionals" includes Teachers, Nurses...etc. In Plant / Machine Operators and Assemblers occupational group, physical ability of men may be reason for 
showing high rates by them than women. However it is not applicable to the senior ranks as well, since that levels work not purely because of their physical ability but also their mental ability. However, noted women's rate on Senior Officials \& Managers and Proprietors \& Managers of Enterprises occupational groups. They show different rates than men and also their contribution to the employment also less.

This compelling situation literature has pointed out as "Glass Ceiling" (GC). It's put on show that there are innumerable barriers, women are facing when they trying to climb the corporate ladder. Evidences suggest that they face an invisible barrier preventing their rise in leadership positions. The metaphor used to implicate this situation is called 'GC' Subsequent metaphors such as "glass elevators" and "glass cliffs" refer to the greater scrutiny and criticism that women may have to face when in leadership roles (Ryan and Haslam, 2005).Simply the term "the GC" refers to invisible or artificial barriers that prevent women from advancing past a certain level (Federal GC Commission [FGCC], 1997). In this circumstance researcher endeavor is to find out the effect of this GC on Woman Career Development (WCD).

\section{LITERATURE REVIEW}

The "GC" is one of compelling metaphors for examining inequalities between, men and women in the workplace (Burke and Vinnicombe, 2005; International Labour Office, 2004; McLeod, 2008). The expression has been used widely in the popular media as well as in official government reports and academic publications (Canberra Bulletin of Public Administration, 1994; Catalyst, 1990; Garland, 1991; Scandura ,1992; State of Wisconsin Task Force on the GC Initiative, 1993; U.S. Department of Labor, 1991).

The barriers that prevent women from ascending to senior management positions in large corporations have often been described by the metaphor "GC", a transparent barrier which prevents women from moving up the corporate ladder past a certain point. (Morrison, White, Van and the center for Creative Leadership, 1987). As per Weyer (2007) the scarcity of female leaders is linked to ongoing prejudice and discrimination against women in the workplace. This refers although women are now capable of moving to upper levels, at some point they are halted by an invisible barriers. It applies to women as a group who are kept from advancing higher because they are women (Morrison et al., 1987).

Auster (1993) points out, however, that the GC is not one ceiling or wall in one spot, but rather many varied and pervasive forms of gender bias that occur frequently in both overt and covert ways.The GC is also very visible to those whose careers have been affected by it. However, the term was used by the U.S. Department of Labor in 1991, in response to a study of nine Fortune 500 companies. The study defined that women and minorities encountered substantial GC barriers in their careers; these barriers were experienced earlier in their professions than previously thought. Researchers found that there are different kinds of GC barriers such as different pay for comparable work.(FGCC,1995), sexual, ethnic, racial, religious discrimination or harassment in the workplace, prevailing culture of many businesses, lack of family-friendly workplace policies (or on the flipside, policies that discriminate against people, non-parents, or single parents)...etc. Human resource experts are often in leadership positions that allow them to have a huge impact on organizations. Consequently it is important that, they are knowledgeable about how the glass- 
ceiling fact may directly or indirectly impact an organization's reputation, customer loyalty, and diversity of skill sets, growth potential and for its bottom line. Also, the Chief Executive Officer or president of an organization may tap Human resource experts for their advice and expertise on the strategic organizational changes that are necessary to reduce the existence of a GC so as to maximize an organization's performance and reputation.

Most of the female felt that while their male counterparts did not have the responsibilities for housework and childcare during their work life, they personally continued to have these responsibilities and that these responsibilities increased their stress level, the family structure has a great impact on career success (Schneer and Reitman, 2002). Married men with kids and a stayat-home wife have the greatest career achievement with respect of salary increase.

Next most successful category is married men who have working wives. Married men whose wives stay at home look after the families have the greatest career pleasure, especially compared to single men. Spouses give additional resources for job performance. The wife not only takes care of household responsibilities, but also provides counsel and work assistance for the husband's job. Executive women do not benefit as much as men from spousal support.

\section{Glass- Ceiling is a myth and self created issue}

According to Rai and Srivastava (2008) corporate argues that no glass ceiling exists. As per them "women were paid lower salaries since they left the jobs midway, worked for lesser time and joined low-risk jobs. Further they argue that at present organizations operate in globally, a number of opportunities for carrier development. It is just myth and self created issue. Their first argument is that women can hold higher positions based on their competencies, through hard work and aspirations. Their second argument is family responsibilities come into the middle of the carrier development.

\subsection{Problem Statement}

Gender differences in promotion within the economics profession have long been a concern of the researches. Since women appear to be under re-presented in senior positions, suggesting they may face a "GC" (Blank, 1996). Though women also be or work as the men worker they may face lot of barriers in their career development. This study is based on female executive level employees, working in private sector organizations in Sri Lanka. Accordingly this study examine the following research questions.

\subsection{Objectives of the Study General Objective}

To find out the effect of GC on WCD of executive level female employees who are working in private sector organizations in Sri Lanka.

\section{Specific Objectives}

1. To evaluate the relationship of GC and WCD of executive level female employees.

2. To measure the effect of GC on WCD of executive level female employees.

3. To recommend solutions for overcoming GC on WCD of executive level female employees. 


\subsection{Significance of the study}

Today most of the people give a considerable attention to GC concept in competitive environment. Most of the researches doing and have done lots of researches about different topics or problems in relevant to women career. Researcher seemed that there is a gap in the empirical knowledge available, in Sri Lankan perspective about the GC. Therefore identifying the impact of GC on women workers is very important to decision makers in identifying key workplace issues in order to develop strategies to address and improve the policies for preventing such things. Furthermore findings of this study would be a better guideline for those who are managers; to identify managerial woman's problems, the ways to shatter those barriers, students; as a referential material for their studies, policy makers; making and improving policies in organizations with regard to GC and WCD findings in this research, and other relevant organization and especially for the all women workers; identifying things which hinder their career and way to shatter them. Also this study would be important to Sri Lankan economy: Through shattering the GC Sri Lankan economy will be beneficial with more participation of working women in their work environment. Also it will help to rise up their earning as well. Research will reveal way for that as it discovers the effect of GC and also describe recommendations for overcoming the effects.

And also it is important for future researches and future job holders as it provide more knowledge on GC that affect women career. As the job holders they will be informed about the ways for securing their jobs or shattering GC. Ultimately it helps to climb up their career. In the case of male job holders they will able to identify problems that faced by their counterparts.

\section{METHODOLOGY}

\subsection{Conceptual Framework}

The main idea emphasized by this conceptual framework is, GC influences the WCD. GC may affect as the independent variable. WCD is the dependent variable.

There for women career life is depending on several independent variables. Cultural Factors (CF), Individual Factors (IF), Organizational Factors (OF) and Family Factors (FF) considered as independent variable in this framework.

CF (beliefs and stereotype),IF (lack of confidence, personal trait sand inability to sell themselves), OF (organizational policy, management style) and FF (childcare, house work)In addition to the above mention factors there can be several intervening variables and moderating variables, such as age, legal factors, norms, environmental factors exist in this study. However they are not considered in the research to avoid unnecessary complexities. For an example, if WCD is influenced by these mentioned variables (moderating and intervening); in consequence WCD may vary indirectly or directly. Thus researcher couldn't precisely measure, effect of GC, because of these other influences, therefore researcher assume here, moderating and Intervening variables as fixed constraint and not affect for WCD.

The model using in the study is as follows:

$$
\begin{gathered}
\mathrm{WCD}=\mathrm{f}(\mathrm{GC}) \\
\mathrm{WCD}=\mathrm{f}(\mathrm{C}, \mathrm{F}, \mathrm{I}, \mathrm{O})
\end{gathered}
$$


where:

$$
\begin{aligned}
& \mathrm{WCD}=\text { Woman Career Development } \\
& \mathrm{C}=\text { Cultural factors } \\
& \mathrm{F}=\text { Family factors } \\
& \mathrm{I}=\text { Individual factors } \\
& \mathrm{O}=\text { Organizational factors }
\end{aligned}
$$

Independent Variable

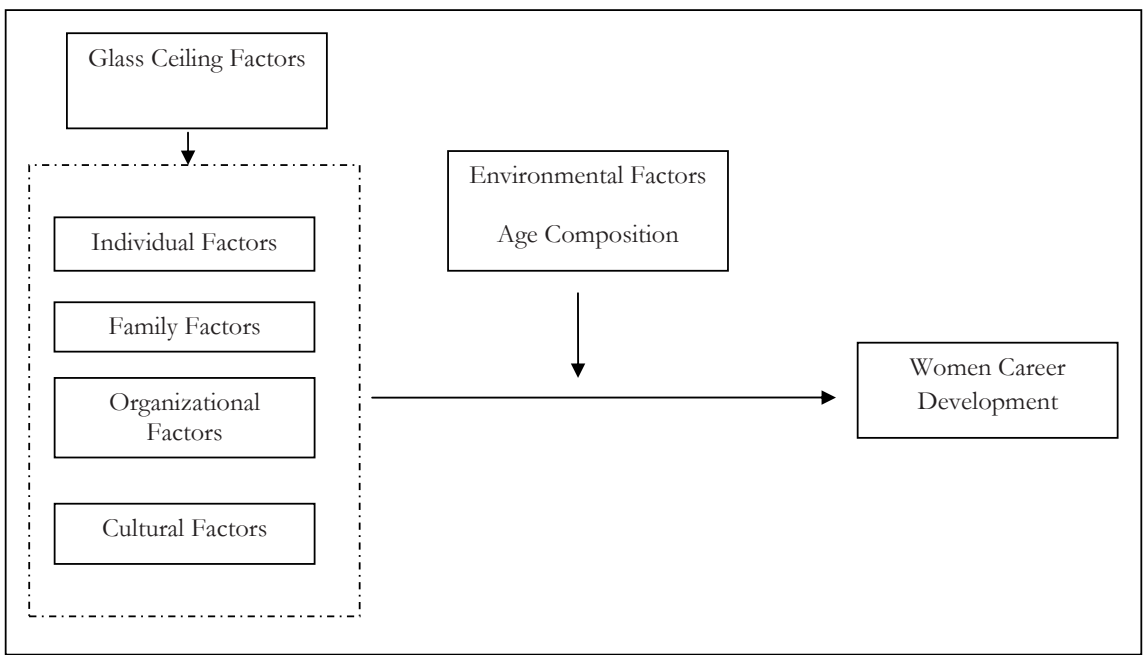

Fig. 1 - Conceptual framework. Source: developed by researcher.

\subsection{Variables of the study}

\section{Independent Variable}

The measurement of GC is based on the four dimensions and these dimensions are IF, FF, OF, and $\mathrm{CF}$.

- Individual Factors - This criterion reflects the extents to which individual barriers that coming from themselves influence the outcome.

- Family Factors - This criterion is the extent to which relation causes affect to the performance of employee.

- Organizational Factors - This reflects the extent to which the employees see the organization as being responsible for lack performance of employee or the extent to which organizational barriers that coming from organizational structure and practices influence the employee development.

- Cultural Factors - This refers to the extent to which the beliefs, traditions, influence the employee development. 


\section{Dependent Variable}

Career Focused The measurement of WCD is based on the three components of WCD Proposed by Afza and Newaz (2008). Those are Career Focused, Family Support and Attitudes towards Organization.

- Career Focused (CF) refers, employee interested in advancing or achieving their career. People with high career focused attempt to develop their profession.

- Family Support (FS)- Family support reflects, the support given by family members to continue success of person's profession. Person who has good or high family support achieve a situation of balancing work-family life and develop their profession.

- Attitudes Towards Organization (AtO) - Attitude towards Organization refers the opinions of employee as regards working organization. People with positive attitudes concerning the organization worked stay with origination and develop their career within it.

\subsection{Rationale of Hypotheses Development}

Maheshwari (2012) indicates GC global barriers can broadly be divided into three categories namely, individual, societal and organization related barriers. According to Williams and Cooper (2004), "women do 65-85 per cent of childcare work and more than 70 per cent of elderly care work". Afza and Newaz (2008) have proposed five major factors which influence GC effects in organizations: Management Perception, Work environment, Work- life conflict, Sexual harassment, Organizational Policy. As study indicates management perception and work environment are most significant factors for creating GC where as organizational policy and work life conflict are the second most significant factors. Conversely respondent disagree about sexual harassment as a contributing factor for creating GC effect in the organization.

Based on the above findings researcher developed and take into consideration four factors which influenced the WCD, namely IF, FF, OF and CF and formulated following alternative hypotheses,

Hypothesis 1 -H1: There is significant impact of Individual Factors on WCD.

Hypothesis 2 - H2: There is significance impact of Family Factors on WCD.

Hypothesis 3 -H3: There is significance impact of Organizational Factors on WCD.

Hypothesis 4 - H4: There is significance impact of Cultural Factors on WCD.

\subsection{Study Design}

This study is undertaken in order to ascertain and be able to describe the characteristics of the variables of interests in a situation. Hence, this study type was descriptive. The objective of the study is to identify the effect of GC on WCD of executive level female employees working in Sri Lanka. Hence, the type of investigation was correlation rather than causal study. A correlation study is conducted in the natural environment of the organization with minimum interference by the researcher with the normal flow of work (Sekaran, 2009). There is some disruption to the normal flow of work in the system as the researcher administers questionnaires at the work place; the researcher's interference in the routine functioning of the system is minimal as compared to that caused during causal studies. 


\subsection{Methodological Choice}

In conducting this study the survey method was used to collect relevant data. Since the researcher wanted to know about employees' attitudes and opinions the present study could be considered as a descriptive one. Moreover, many primary data were collected to diagnose the problem centred here and to answers the researches questions and achieve the objectives. Thus the survey method regarded as most suitably.

\subsection{Population, sample and sample selection method}

The population of the study was the executive level female employees who exceed their thirty age's limit and who employed in private sector organizations in Sri Lanka. The clustered and simple random sampling techniques were used to select the sample of the study. To select the sample, the entire country divided into 26 districts that is second level administrative division in Sri Lanka and selected Gampaha district as a clustered area for the research. Under the second stage it was selected 150 women executives randomly to the sample.

\subsection{The Instrument Used for Data Collection}

This research study relied upon the survey method for collection of data; the questionnairebased survey has become one of the most widely used techniques. A self-administered questionnaire was developed as the survey instrument.

The questionnaire consists of two parts namely part A, part B. The questionnaires were prepared in the English language as well as in the Sinhala language. Part A is the personal profile. The respondent's, biographical information was collected to establish a profile of the sample group in relation to gender, marital status, age, educational qualifications, position, average income and length of service.

Part B consists of 25 questions based on the four GC dimensions and the three WCD dimensions to measure the GC and WCD with five point scale ranging. The questionnaire is presented in a Likert -type scale with Strongly Disagree forming the one end of the continuum and Strongly Agree the other end.

After formulation of the preliminary questionnaire, for the purpose of testing the reliability, accuracy and validity of those questions it was subjected to pilot survey. The respective questionnaire was directed to 20 executive level female workers. The reliability score of the pilot survey (Cronbach Alpha) is in between 7 to .9.

\section{DATAANALYSIS AND DISCUSSION}

\subsection{Descriptive statistics}

According to the above data, 76 employees are married and 42 employees are unmarried. Also 2 female employees represent widow category. In here married employees are majority and it gets the $63 \%$ of the sample. The sample was consisted, with the majority of respondents being between the ages of 30-35 (70.80\%\%). 20\% were between $36-40.8 .30 \%$ were between $41-45$. $0.80 \%$ were above 51 years of age and no one included in age category of 46-50. According to the above data 4 employees have been passed the $\mathrm{O} / \mathrm{L}$ examination and 36 employees have been passed A/L. Also 12 executives have been done diploma. In here majority of the sample were having the Basic Degree, representing highest percentage of $30.80 \%$. And also $25 \%$ respond- 
ents were with the professional qualification and it gets 30 of the sample. $0.80 \%$ (1) respondents were post graduates. $1.70 \%$ survey respondents were Assistant managers and $15 \%$ were Coordinators. Majority of the sample employees were executives, representing 46 of the sample. Also $12.50 \%$ were junior Executives, $4.20 \%$ were Managers and Staff Officers represented $28.30 \%$ and it gets 34 of the sample. Majority of employees have less than three year working experience in this sample of the study. It gets the $44.17 \%$ of the sample. $25 \%$ of the respondents are employed for more than 7 years. $30.83 \%$ of the sample respondents were in between 3-7 years working experience.

\subsection{The relationship of GC and WCD}

Tab. 4 - Correlation between GC and Dimensions of WCD. Source: survey data, 2012.

\begin{tabular}{|c|c|c|c|c|c|}
\hline & & WCD & CF & FS & AtO \\
\hline Glass Ceiling & Pearson Correlation & $-.464 * *$ & $-.243^{* *}$ & $-.462 * *$ & $-.331^{* *}$ \\
\hline & Sig. (2-tailed) & 0.000 & 0.008 & 0.000 & 0.000 \\
\hline & $\mathrm{N}$ & 120 & 120 & 120 & 120 \\
\hline
\end{tabular}

** Correlation is significant at the 0.01 level (2-tailed).

According to the above Table 4 the correlation coefficient between GC and CF is, $\mathrm{r}=-.243$ with the significant value .008. The $\mathrm{r}$ value is less than -.25 . It is clear that there is a weak negative co-relation between the GC and CF. and also Correlation is significant at the 0.01 level. Also correlation coefficient between GC and FS is, $r=-.462$ with the significant value .000 . The $r$ value is greater than -.25 and less than -.75. It is clear that there is a moderate negative co-relation between the GC and WCD. Correlation is significant at the 0.01 level. According to the above tab the correlation coefficient between GC and AtO is, $\mathrm{r}=-.331$ with the significant value .000 . The $\mathrm{r}$ value is greater than -.25 and less than -.75. It is clear that there is a moderate negative co-relation between the GC and AtO. And also Correlation is significant at the 0.01 level. Correlation coefficient between GC and WCD is, $r=-.464$ with the significant value .000 . The $r$ value is greater than -.25 and less than -.75. It is clear that there is a moderate negative co-relation between the GC and WCD. And also Correlation is significant at the 0.01 .

\subsection{Measure the effect of GC on WCD of executive level female employees}

The results of Multiple Regression Analysis of independent variable (GC) against the dependent variable (WCD) are shown in the Table 5.

Tab. 5 - Results of Multiple Regression Analysis. Source: Survey data, 2012.

\begin{tabular}{|c|c|c|c|c|}
\hline Model & $\mathrm{R}$ & $\mathrm{R}$ Square & $\begin{array}{c}\text { Adjusted R } \\
\text { Square }\end{array}$ & $\begin{array}{c}\text { Std. Error of the } \\
\text { Estimate }\end{array}$ \\
\hline 1 & $.523(\mathrm{a})$ & .274 & .249 & .38149 \\
\hline
\end{tabular}

a. Predictors: (Constant), Cultural Factor, Organizational Factor, Individual Factor, Family Factor 


\begin{tabular}{|c|c|c|c|c|c|c|}
\hline \multicolumn{7}{|c|}{ Coefficients (a) } \\
\hline \multirow[t]{2}{*}{ Model } & & \multicolumn{2}{|c|}{$\begin{array}{l}\text { Unstandardized } \\
\text { Coefficients }\end{array}$} & \multirow{2}{*}{$\begin{array}{c}\text { Standardized } \\
\text { Coefficients }\end{array}$} & \multirow{2}{*}{$\begin{array}{l}. \mathrm{T} \\
\mathrm{B}\end{array}$} & \multirow{2}{*}{$\begin{array}{c}\text { Sig } \\
\text { Std. Error }\end{array}$} \\
\hline & & $\mathrm{B}$ & Std. Error & & & \\
\hline \multirow{5}{*}{1} & (Constant) & 5.217 & .222 & & 23.505 & .000 \\
\hline & $\begin{array}{l}\text { Individual } \\
\text { Factor }\end{array}$ & -.278 & .073 & -.360 & -3.824 & .000 \\
\hline & $\begin{array}{l}\text { Family } \\
\text { Factor }\end{array}$ & .053 & .067 & .075 & .798 & .426 \\
\hline & $\begin{array}{l}\text { Organi- } \\
\text { zational } \\
\text { Factor }\end{array}$ & -.093 & .046 & -.166 & -2.024 & .045 \\
\hline & $\begin{array}{l}\text { Cultural } \\
\text { Factor }\end{array}$ & -.155 & .066 & -.222 & -2.358 & .020 \\
\hline
\end{tabular}

a .Dependent Variable: WCD

R .523 is the Multiple Correlation Coefficient of the independent variable with the dependent variable after all the inter correlations are taken into account. R Square .274 is the explained variance in WCD by the combination of these variables. F value10.840 is significant at .000 level. The results indicate that $27.4 \%$ of the variance of WCD has been significantly explained by GC. Hence it can be clearly said that other factors have $72.6 \%$ influences on WCD.

Coefficients tab helps to see which among the independent sub variables influence most the variance of WCD. By looking at Beta under standardized coefficients, it is concluded that IF is the most influenced factor to the WCD and it is significant at .000 level.

From coefficients tab can be seen that when the other variables are controlled only IF, OF and CF show significant correlation with WCD. FFs' P value indicate .426 that is more than the value of .05 , hence it is not significantly predictive of WCD. Tab 4.20 depicts that FF is significantly correlated with WCD when that factor considered individually. This is a contradiction, but this could be happen in multiple regressions. The variance that the first independent sub variable shares with the dependent variable could overlap with the variance that is shared between second sub variable and dependent variable. As per this research results except FF, other factors are significantly predictive of WCD.

\subsection{Testing of hypotheses}

Researcher used multiple regression analysis to test the alternative hypotheses and null hypotheses of the study and to achieve main objective of the study. The results of the analysis are illustrated by the 4.28 tab. Here P value was used to check the significance. If the P value is equal or less than 0.05 then the null hypothesis is rejected.

Hypothesis 1 - H1: There is significant impact of Individual Factors on WCD.

Coefficients tab depicts, $\mathrm{P}<0.05$, indicating that significant impact of IF on WCD. Thus analysis reveals enough statistical evidence to accept the alternative hypothesis that "There is significant impact of IF on WCD." It is accepted at the 5\% significance level or at the $95 \%$ confidence 
level.

Hypothesis 2 - H2: There is significance impact of Family Factors on WCD.

Coefficients tab depicts, $\mathrm{P}>0.05$, indicating that non significant impact of FF on WCD. Thus analysis fails to reject the null hypothesis of "There is no significant impact of Family Factors on WCD".

Hypothesis 3 - H3: There is significance impact of OF on WCD.

Coefficients tab depicts, $\mathrm{P}<0.05$, indicating that significant impact of OF on WCD. Thus analysis reveals enough statistical evidence to accept the alternative hypothesis that "There is significant impact of OF on WCD" It is accepted at the 5\% significance level or at the $95 \%$ confidence level.

Hypothesis 4 - H4: There is significance impact of Cultural Factors on WCD.

Coefficients tab depicts, $\mathrm{P}<0.05$, indicating that significant impact of $\mathrm{CuF}$ on WCD. Thus analysis reveals enough statistical evidence to accept the alternative hypothesis that "There is significant impact of CF on WCD." It is accepted at the 5\% significance level or at the 95\% confidence level.

Tab. 6 - Summary of Hypotheses testing. Source: constructed by the researcher.

\begin{tabular}{|c|c|c|}
\hline Hypothesis & Accepted & Rejected \\
\hline 1 & $\checkmark$ & \\
\hline 2 & & $\checkmark$ \\
\hline 3 & $\checkmark$ & \\
\hline 4 & $\checkmark$ & \\
\hline
\end{tabular}

According to analyze data of the study it has confirmed that there is a moderate negative correlation between GC and WCD among the Female Executive employees. Correlation coefficient value is $r=-.464$ and the significant value is .000 . Hence this relationship is significant at the $1 \%$ significant level or at the $99 \%$ confidence level. According to the above analysis of correlation, the increase in GC causes to decrease in WCD at moderate decreasing since correlation indicates negative moderate relationship. The independent variable, GC was composed of four sub variables and the study has revealed the relationship between each sub variable of GC and WCD. A moderate negative co-relation could be seen between IF and WCD. The correlation value is -.451 and the significant value is .000 . It implies that there is a significant relationship between two variables. Correlation coefficient between FF and WCD is $r=.-.223$ with the significant value .015. It is clear that there is a weak negative co-relation between the FF and WCD. And also there is a significant relationship between two variables. The correlation value for OF and WCD is $r=-.259$ with the significant value .004 . The result clearly revealed that there is a moderate negative co-relation between the OF and WCD. Also there is significant relationship between two variables. A moderate weak correlation could be seen between CF and WCD. Its value is $\mathrm{r}$ $=-.385$ and the significant value .000 . Hence it is significance at the $1 \%$ significance level or at the $99 \%$ confidence level.

The findings of the correlation analysis reveal that the third objective that "to analyze the rela- 
tionship of GC and WCD of executive level female employees who are working in private sector organizations in Sri Lanka." is achieved. According to the analyzed data of the study it has confirmed that the GC has $27.4 \%$ influences on the WCD among Female Executive level employees working in private sector organization in Sri Lanka. And also it is statistically significant at the $5 \%$ significance level or at the $95 \%$ confidence level. Hence it can be clearly said that other factors have $72.6 \%$ influences on WCD. The findings of the regression analysis reveal that the fourth objective that "to measure the effect of GC on WCD of executive level female employees who are working in private sector organizations in Sri Lanka" is achieved. From the coefficient tab it is proved that only IF, OF and CF show significant correlation with WCD. FFs' P value indicate .426 that is more than the value of .05 , hence it is not significantly predictive of WCD. According to the above results researcher fail to reject null hypothesis only in Second hypothesis, which is "there is no significant impact of Family Factors on WCD". Apart from that in all other three hypotheses, an alternative hypothesis is achieved proving that there is significant impact of Individual Factors, OF and CF on WCD. This was accepted at the 5\% significance level or at the $95 \%$ confidence level.

\subsection{Material state impact on WCD}

"A one-way between subjects ANOVA was conducted to compare the Material State (MS) on I, F, O and $\mathrm{C}$ effects on WCD. There was a no significant effect of IF at the $\mathrm{p}<.05$ level for the three conditions $[\mathrm{F}(2,117)=, 280, \mathrm{p}=0.756]$. Taken together, these results suggest that MS do have an effect on Level of IF effect on WCD. Respectively MS was a no significant effect on FF , OF, and $\mathrm{CF}$ at the level for three conditions $[\mathrm{F}(2,117)=2.410, \mathrm{p}=0.94],[\mathrm{F}(2,117)=1.592, \mathrm{p}$ $=0.208]$ and $[\mathrm{F}(2,117)=1.753, \mathrm{p}=0.178]$.

\subsection{GC impact on different managerial positions}

According to its results "A one-way between subjects ANOVA was conducted to compare the managerial levels on WCD. There was a no significant effect of the current working capacity on WCD at the $\mathrm{p}<.05$ level for the three conditions $[\mathrm{F}(2,117)=.563, \mathrm{p}=0.571]$. Taken together, these results suggest that whatever the managerial position women held there is no significant different in GC influence.

\section{GAIN FOR SCIENCE AND PRACTICE}

Throughout the study researcher indicate particular factors which create the GC effects and factors that contribute to the improvement of WCD. Firstly researcher identified four factors namely IF, FF, OF and CF which helps to downward the women career life. Concerning the Individual barriers, researcher identified factors such as lack of self confidence, negative attitudes. For Family barriers identified such as childcare, home responsibilities, and family and friends. Different management styles, unfair promotion practices serve as the Organizational barriers In the course of analysis researcher indicates that increasing GC barriers would result in the decreases of WCD at moderate level(Correlation between GC and WCD=-.464).In the case of analysis sub variable of GC found that increasing IF, CF and OF also result to decrease the WCD al moderate level, but FF would result to decrease the WCD al low level. With the help of corre- 
lation and regression analysis (Beta and $\mathrm{P}$ value) also discover the importance or most powerful factors among the considered GC Factors which results to decrease the WCD. According to the respondent's opinion Individual barriers are the most significant factors for creating GC where as Cultural barriers and Organizational barriers are the second and third most significant factors. On the other hand respondent kept Family barriers at lowest (among considered four).

With regard to WCD Research determine that Career Focused, Family Support and Attitude towards Organization influence the career advancement of women. Having the career path, dedication to the work duties and making the relationships would determine the Career Focused of Women. Appreciation of family members and work life balance would determine the Family Support. Team work and employee perception would serve as the determining factors of AtO. As the research identified factors of GC and WCD to the theoretical aspect, finding and recommendations would also supportive to the implementing the businesses. Hence Organization can take steps to overcome the identified most affective GC factors and to improve the WCD also can be applied for developing women empowerment.

\section{CONCLUSION OF THE STUDY}

The main objective of this research was to find out the effects of GC on WCD of executive level female employees who are working in private sector organizations in Sri Lanka. Overall, this research showed that the GC has $27.4 \%$ influences on the WCD among the Female Executive level employees working in private sector organization in Sri Lanka. And also it is statistically significant at the 5\% significance level or at the $95 \%$ confidence level. Hence it can be clearly said that other factors have $72.6 \%$ influences on WCD.

The level of GC of Sri Lanka is measured using the mean value. The above data reveal that the majority of the respondents exhibited low level of influence of GC. And also four sub variable of GC lie within the range of low level. At the same time, mean value is used to measure the current level of WCD. Findings of the study reveal that the majority of the respondents exhibited satisfactory level of WCD. As well as mean values of the Career Focused, Family Support and Attitudes towards Organization lie within the range of satisfactory level.

According to the analyzed data of the study it has confirmed that there is a moderate negative correlation between GC and WCD among the Executive level female employees working in private sector organization and this relationship is significant at the 1\% significant level or $99 \%$ confidence level. The study has revealed that there is a weak negative correlation between FF and WCD. At the same time, there is a moderate negative correlation between other three sub variables of GC and WCD. As well as all this correlations are statistically significant at the $1 \%$ significant level or $99 \%$ confidence level. Through multiple regression it is reveal that IF, OF and CF are significantly affect for the WCD. The findings of the overall analysis of the study reveal that the general objective of the study that "to find out the effect of GC on WCD of executive level female employees who are working in private sector organizations in Sri Lanka." is achieved.

\subsection{Recommendations of the Study}


This research has identified some factors which are responsible for creating GC effects. It also revealed some factors which help women to advance their career growth. Under this, it is expected to point out a set of recommendations enabling to enhance the existing level of WCD. Accordingly, following recommendations are made.

According to research findings among the GC factors most influenced factor is IF. Hence Female workers must work to avoid the individual barriers such, lack of self confidence, being too emotional when working matters of workers by developing the self confidence and positive thinking as such building can do perception. They must change the perception regarding women workers as posy, emotional, manipulative.

Female workers who identified having difficulties balancing work and family indicated that they had too many work and family responsibilities and sometimes they did not have time to accomplish everything effectively. To them, time management was the biggest challenge. To avoid the Family Barriers organization can help with the female workers by offering day care centers, leave them in the weekends, giving same flexible office hours and home office. Some can argue that leaving the females in weekends will affect the organization performance but to get the fullest contribution of the creative's, talented organization must give something and expect something from them. Other factor is that our society has been built to bear the family responsibilities to women hence that must be a fair reason to give little bit freedom to them.

Most of the employees of the study did not agreed with the fairness of the promotion scheme of the organization. Hence management should handle the employee promotion decisions fairly. It is better to provide same rights and responsibilities to male and female within the organization as such same promotion practices, same salary level according to the experience and knowledge level, same work responsibilities. Also organization can have awareness program to change the workers perceptions on women leaders since most of the respondent have agreed that male workers are discomfort having them as seniors. Furthermore majority of the respondents did not agree with the "equal treatment of the management." Therefore management should engage each employee individually and map a clear and concise succession path for each individual.

As the respondents exhibited Second influential GC factor is cultural factors. Here most powerful barrier is gender stereotyping. If the work females want to change the attitudes of others regarding traditional myth that women are home makers and they cannot work as males, they must show that they able to do work at maximum level as organization expect. Organization also could help to female workers by examining the organization's informal culture, traditions and norms that may work against women and conducting awareness program to bring to an end of those. Also to enable women who are in employment to advance their careers organization could support the provision of training and other developmental mechanisms that will also effect to change their attitudes regarding organization to a positive side.

\section{References}

1. Adler, N. J., \& Izraeli, D. N. (1994). Competitive frontiers: Women managers in a global economy. Cambridge, MA.: Blackwell.

2. Afza, S., \& Newaz, M. (2008). Factors determining the presence of GC and influencing women career advancement in bangladesh. Bbrac University Journal, 5(1), 85-92.

3. Auster, E. R. (1993). Demystifying the GC: Organizational and interpersonal dynamics of 
gender bias. Business and the Contemporary World, 5, 47-68.

4. Barnet-Verzat, C., \& Wolff, F-C. (2008). Gender wage gap and the glass ceiling effect: a firm level investigation. International Journal of Manpower, 29(6), 486-502. http://dx.doi. org $/ 10.1108 / 01437720810904185$

5. Bilimoria, D., \& Piderit, S. K. (1994). Board committee membership: Effects of sex-based bias. Academy of Management Journal, 37(6), 1453-1477. http://dx.doi.org/10.2307/256795

6. Black, J. S., \& Gregerson, H. B. (1999). Globalizing people through international assignments. Reading MA: Addison Wesley.

7. Blank, R. M. (1996). Report of the committee on the status of women in the economics profession. American Economic Review, 86(2), 502-506.

8. Booysen, L.A.E., \& Nkomo, S.M. (2010). Gender role stereotypes and requisite management characteristics: The case of South Africa. Gender in Management: An International Journal, 25(4), 285-300. http://dx.doi.org/10.1108/17542411011048164

9. Caligiuri, P. M., \& Tung, R. (1999). Comparing the success of male and female expatriates from a us-based company. International Journal of Human Resource Management, 10(5), 163-179. http://dx.doi.org/10.1080/095851999340143

10. Canberra Bulletin of Public Administration. (1994). The GC: Illusory or real? Canberra Bulletin of Public Administration.

11. Catalyst (1990). Women in corporate management: Results of a catalst survey. New York: Catalyst.

12. Cooper, D. R., \& Schindelr, P. S. (2001). Business research methods. Sydney: McGraw-Hill.

13. Davidson, M. (2009). The glass ceiling - Australian and British women in management 2009: myth or reality? Paper presented at the 44th Australian Psychological Society Annual Conference, September 30 - October 4, 2009. Darwin, Australia.

14. Directors and Boards (1992). Spotlight on women directors, 16(4), 66-68.

15. Dreher, G. F., \& Ronald, A. A. (1990). A comparative study of mentoring among men and women in managerial, professional and technical positions. Journal of Applied Psychology, 75(5), 539-546. http://dx.doi.org/10.1037//0021-9010.75.5.539

16. Eagly, A.H., \& Carli, L.L. (2007). Through the labyrinth: The truth about how women become leader. Boston, MA: Harvard Business School.

17. Eagly, A.H., \& Karau, S.J. (2002). Role congruity theory of prejudice toward female leaders. Psychological Review, 109(3), 573-598. http://dx.doi.org/10.1037//0033-295X.109.3.573

18. Fassinger, R.E. (2008). Workplace diversity and public policy: challenges and opportunities for psychology. American Psychologist, 63(4), 252-268. http://dx.doi.org/10.1037/0003066X.63.4.252

19. Federal GC Commission (1995). Good for Business: Making Full Use of the Nation's Human Capital. Washington, D.C.: U.S. Department of Labor.

20. Federal GC Commission (1997). The GC. In Dunn D. (ed.), Workplace/women's place: an anthology. (226 -233). Los Angeles, CA: Roxbury Publishing.

21. Garland, S. (1991). Throwing stones at the GC. Business Week, 29.

22. Maginn, P.J. (2010). Breaking through the glass ceiling of local government? The gender profile of 
Australian mayors in metropolitan Australia 1985-2010. FactBase Bulletin 11, The University of Western Australia and Committee for Perth, Perth.

23. Mathur-Helm, B. (2006). Women and the glass ceiling in South African banks: an illusion or reality? Women in Management Review, 21(4), 311-326. http://dx.doi.org/10.1108/096494206 10667028

24. Meyerson, D. E., \& Fletcher, J K. (2000). A Modest Manifesto for Shattering the Glass Ceiling. ADVANCE Library Collection, Paper 190.

25. Morrison, A. M., White, R. P., Velsor, E., \& The Center for Creative Leadership (1987). Breaking the GC: Can women reach the top of America's largest corporations? Reading, MA: AddisonWesley.

26. Prickett, R. (2008). Uplift and Support. Financial Management, 5, 22-26.

27. Rai, U. K. \& Srivastava, M. (2008). Women Executives and the glass ceiling: Myths and Mysteries From Razia Sultana to Hillary Clinton. BHU Management Review, 1(2), 79.

28. Ryan, M., \& Haslam, A. (2005). The glass cliff: Evidence that women are over-represented in precarious leadership positions. British Journal of Management, 16(2), 81-90. http://dx.doi. org/10.1111/j.1467-8551.2005.00433.x

29. Scandura, T. (1992). Breaking the GC in the 1990s. Washington, DC: U.S. Department of Labor Women's Bureau.

30. Schneer, J., \& Reitman, F. (2002). Managerial life without a wife: Family structure and managerial career success. Journal of Business Ethics, 37(1), 25-38. http://dx.doi.org/10.1023/ A:1014773917084

31. Sekeran, U. (2009). Research Methods for Business, A Skill Building Approach. New Delhi: S.P.Printers.

32. State of Wisconsin Task Force on the GC Initiative (1993). Report of the governor's task force on the GC initiative. Madison: State of Wisconsin, Wisconsin Women's Council.

33. Still, L.V. (2006). Where are the women in leadership in Australia? Women in Management Review, 21(3), 180-194. http://dx.doi.org/10.1108/09649420610657371

34. Tan, J. (2008). Breaking the "bamboo curtain" and the "glass ceiling": the experience of women entrepreneurs in high-tech industries in an emerging market. Journal of Business Ethics, 80(3), 547-564. http://dx.doi.org/10.1007/s10551-007-9454-9

35. Thomson, P., Graham, J., \& Lloyd, T. (2008). A woman's place is in the boardroom: the roadmap. Basingstoke, Hampshire: Palgrave Macmillan, Houndmills. http://dx.doi.org/10.1057/978 0230583955

36. U.S. Department of Labor (1991). A report on the GC initiative. Washington, DC: Government Printing Office.

\section{Contact information}

A. Chamaru De Alwis

Department of Human Resource Management

Faculty of Commerce and Management, University of Kelaniya, Sri Lanka

Email:dealwisac@gmail.com

JEL Classification: M12, O15, J16 